\title{
Environmental education in the Upper Paraná River floodplain, municipality of Porto Rico (Paraná State), Brazil
}

Received November 18, 2008 - Accepted March 10, 2009 - Distributed June 30, 2009

\begin{abstract}
Since 2003, researchers, faculty, graduate and undergraduate students from the State University of Maringá have been working alongside teachers from the state and local schools in the municipality of Porto Rico (Paraná State), located on the banks of the Paraná River. Their objective is to outline actions and strategies with the purpose of building methodological paths to insert environmental education into the school curriculum. Based on the action-research methodology, the group has developed the following programs: a) the Continuing Education Program in Environmental Education; b) the Development of Interdisciplinary Projects; c) the Insertion of Information and Communication Technologies (ICTs); and d) the Production of Teaching Materials. The evaluations of the programs indicate that teachers have been able to gradually build a theoretical and methodological basis for environmental education while simultaneously growing into the role of teacher-researchers as they create the conditions to investigate their pedagogical practices, reflect upon them, share experiences, innovate, and make the teaching-learning process more significant. Allied to the advances in educational practices and with the aid of ICTs, the activities developed in the classroom, in the field and in the lab - all of which involve natural and cultural aspects of the region - have contributed to teachers' and students' better understanding of the ecological, cultural, social and economic value of the floodplain, and consequently, of the importance of preservation and management in order to maintain local biodiversity.
\end{abstract}

Keywords: teacher formation, middle and high school, Information and Communication Technology (ICT), Paraná River, floodplain.

\section{Educação ambiental na planície alagável do Alto Rio Paraná, Porto Rico - PR, Brasil}

\section{Resumo}

Desde 2003, pesquisadores, professores, pós-graduandos e graduandos da Universidade Estadual de Maringá vêm trabalhando em conjunto com os professores das escolas, estadual e municipal, do município de Porto Rico - PR, localizado às margens do Rio Paraná, com o objetivo de delinear ações e estratégias, no sentido de construir caminhos metodológicos para a inserção da educação ambiental no currículo escolar. Com base na metodologia da pesquisaação, o grupo vem desenvolvendo alguns programas: a) Programa de Educação Continuada em Educação Ambiental; b) Desenvolvimento de Projetos Interdisciplinares; c) Inserção de Tecnologias de Informação e Comunicação (TICs); d) Produção de Material Didático. As avaliações dos programas indicam que, gradativamente, os professores têm construído uma base teórica e metodológica da educação ambiental e, ao mesmo tempo, tem desenvolvido uma postura de professor-pesquisador, ao criar condições de investigação de sua prática pedagógica, de refletir sobre a mesma, de trocar experiências, de inovar, de tornar o processo de ensino-aprendizagem mais significativo. Aliado 
ao aprimoramento das práticas educacionais, e com o apoio das TICs, as atividades desenvolvidas, em sala de aula, campo e laboratório, abordando aspectos naturais e culturais da região, têm contribuído para que professores e alunos compreendam melhor o valor ecológico, cultural, social e econômico da planície e, consequentemente, da importância da conservação e manejo da mesma para a manutenção da biodiversidade local.

Palavras-chave: formação de professores, ensino fundamental e médio, Tecnologias de Informação e Comunicação (TIC), planície de inundação, Rio Paraná.

\section{Introduction}

It is impossible to discuss the preservation of biodiversity, manageable use of natural resources and sustainable development practices in the remainder of the Paraná River floodplain without mentioning environmental education. The processes of occupation and development in the region have put pressure on the natural resources, which in turn has compromised the viability of the traditional economy (fishing and agriculture), the ecological integrity of the wetland environments, and consequently, the quality of life for the local population. Only with a clear understanding of natural and cultural practices and processes will it be possible to have active and critical participation by various social actors regarding the existing environmental predicament.

One of the priorities of the project "The Paraná River Floodplain: Structures and Processes" of the Long-Term Ecological Research Program (PELD) is the development of research and projects for environmental education in formal and non-formal schooling, with the objective of promoting greater interaction between the university and the regional communities. The main goal of this interaction is to share with the local school community the scientific knowledge gathered by the State University of Maringá (UEM) - particularly by the Graduate Program in Ecology of Continental Aquatic Environments (PEA), the Nucleus for Research in Limnology, Ichthyology and Aquaculture (Nupélia), the Multidisciplinary Environment Study Group (GEMA), and the Socio-Environmental Study Group (GESA) - on the existing ecological, economic and social components of the floodplain, as well as to promote dialogue and exchange of experiences among the learning institutions and to build partnerships to search for sustainable solutions.

Some studies were conducted with the public schools in the town of Porto Rico, a town located near the Paraná River. These studies focused on environmental education as scientific education (Medeiros, 2000); environmental education and the study of social representations (Tomanik and Tomanik, 2002); and environmental education and semiotics (Medeiros, 2003).

Under this framework, since 2002, faculty, researchers, and graduate and undergraduate students at UEM have been working alongside local schools with the objective of creating actions and strategies to build methodological paths to insert environmental education into the school curriculum. The basic assumption is that the school, as a place for developing the skills, competencies and values that form the core of civic formation, plays a fundamental role in disseminating the principles and practices of environmental education.

This study aims to present the fundamentals, practices and methodologies applied in the programs and projects of environmental education currently under implementation in the PELD, with the objective of expanding the debate on the paths and challenges of this teaching field. Our goal is to establish strategies that contribute to changes in values and practices - by students, faculty and the general community - under a framework that values the floodplain of the Paraná River.

\section{Environmental Education: Fundamentals for an Engaging Practice}

The environmental question presents itself as one of the main concerns of contemporary societies. In spite of our scientific potential and unquestionable technological progress, we are experiencing an escalation of countless environmental and social problems - pollution of rivers and oceans, air and soil contamination, depletion of renewable and non-renewable natural resources, global warming, destruction of the ozone layer, loss of biodiversity, cultural impoverishment, social injustices, violence, hunger, and others, which have drastically compromised quality of life. This global crisis reinforces the need for a reevaluation of the development models adopted by contemporary societies.

Within this already disturbing scenario, globalization and its demands require a different form of thinking - a new way of looking at the world, in which humankind acknowledges it responsibility as an integral part of this complex web of relationships and its accountability for a significant part of the environmental crisis.

To that end, environmental education emerges from the perspective of providing people with an understanding of their natural and cultural environment while also enabling the development of new rules, practices and values encouraging the sustainable use and development of natural resources and the improvement of quality of life for all living beings.

Ever since the Intergovernmental Conference on Environmental Education held in Tbilisi, Georgia in 1977, environmental education has been regarded as an essential component for nature preservation and sustainable development. At that event, organized by UNESCO 
in co-operation with the United Nations Environmental Programme, environmental education was defined as:

A dimension given to the content and practice of Education, focused on the resolution of concrete environmental problems through interdisciplinary approaches, and active and responsible participation from each individual and the collectivity (Dias, 1992 p. 31).

Since Tbilisi, several events and documents have emphasized the importance of inserting environmental education into all levels and modalities of both formal and informal learning. It should be the responsibility of governments, learning institutions, and mass media, as well as public and private organizations, to create mechanisms that promote environmental education.

To that end, several countries have incorporated environmental education into their formal educational systems at the primary and secondary levels, with variations according to social, economic, cultural and institutional contexts (Scoullos and Malotidi, 2005).

In Brazil, Law 9.975/99, which instituted the National Environmental Education Policy, states in Article 10 that environmental education must be developed in an integrated, continuous and permanent form at all levels and modalities of formal education. However, although the Ministry of Education (MEC) launched the National Curriculum Parameters (PCNs) in 1997 with guidelines for dealing with the theme of the environment using a cross-disciplinary approach, many teachers still encounter difficulties in working the environmental question into their daily teaching practices. Many of the initiatives are limited to isolated activities - planting seedlings, selective garbage collection, making posters, visits to parks and reserves, observations of polluted rivers, among other things - performed mostly on commemorative dates, such as Environment Week, Tree Day, Water Day, etc. Although valid, these awareness-building activities are not enough to shape attitudes, values and knowledge and develop a more critical form of thinking if they are not conducted within a broader educational process.

Researchers have reached a consensus that environmental education, as a nascent field of knowledge with theoretical and methodological specificities, demands a specific organization for the professionals responsible for its development (Medina, 2002; Zakrzevski and Sato, 2001; Guimarães, 2004; Taglieber, 2004; Tristão, 2004).

Given this perspective, several graduate programs, especially at the specialization level, were created at the various universities and colleges in the country with the objective of teaching faculty and professionals who deal with the environment about the theoretical and practical fundamentals of environmental education. One of the pioneers in that field is the Specialization Course in Environmental Education and Water Resources, created in 1997 at the University of São Paulo (São Carlos, SP), which emphasizes the process of environmental education and uses the hydrographic basin as the basic research unit (Mateus and Sé, 2003). At the Master's and Doctorate levels, the Graduate Program in Environmental
Education at the Federal University of Rio Grande (Rio Grande, RS) aims to form research faculty capable of contributing to the production and transformation of knowledge in the field of environmental education with a scientific, humanistic and interdisciplinary focus on environmental, ecological and socio-environmental issues. There are also several Master's and Doctorate programs in different areas of knowledge that include environmental education in their programs, such as the Graduate Program in Ecology and Natural Resources (Federal University of São Carlos, SP) and the Graduate Program in Environment and Development (Federal University of Curitiba, PR), among others.

Guerra and Taglieber (2007) further added that an academic experience in environmental education should not be reduced to training or certification, much less to transmitting ecological knowledge, but rather should consist of valuing a reflexive praxis.

Reinforcing this concept, Guimarães (2004) emphasizes that the formation of faculty under the framework of "critical environmental education" aims to form educators capable of reflecting critically on their teaching practices and on the complex socio-environmental dynamics in which the school and society at large operate.

To that end, teacher accreditation programs and courses, as well as continuing education programs in environmental education, have begun to employ participative methodologies as investigative work strategies for the teaching practice (Zakrzevski and Sato, 2001; Tozoni-Reis, 2007; Lucatto and Talamoni, 2007; Guerra and Taglieber, 2007).

Starting in the 1980s, "action-research", which is a modality of research developed in the social sciences, has been widely used in education and environmental research to find new channels of knowledge between researchers and subjects. The main characteristic of this type of participative methodology is the possibility that subjects problematize the contradictions and difficulties experienced by the group throughout their teaching practice with the objective of finding ways to overcome them (Thiollent, 2000).

In the courses and programs developed at PELD, action-research stands out as a proposal for collaborative work; based on the identification of the problems and difficulties faced by the schoolteachers regarding the introduction of environmental content into daily teaching practice, a collective analysis and deliberation is established between the teachers and UEM researchers with the objective of broadening the methodological and theoretical vision of the group. Consequently, strategies are proposed to overcome the obstacles raised.

The aim of the collaborative work is, above all, to establish a dialogue between the university and the school community of Porto Rico to share experiences and, together, to create learning paths that enable the formation of students who are more critical of and outspoken about environmental transformations. 


\subsection{Continuing education program in environmental education}

The Continuing Education Program in Environmental Education began in 2003 at the State Middle and High School located in the municipality of Porto Rico - Paraná State.

The UEM faculty's initial contact with the school had the objective of proposing a partnership to develop environmental education research and projects in order to integrate environmental issues into the school curriculum.

During the preliminary meetings, the schoolteachers demonstrated great enthusiasm in learning more about the work developed by the university in the region. To them, the lack of communication between the researchers and the local community generated quite a bit of curiosity and mistrust regarding the investigations and field activities that were conducted periodically by researchers in the floodplain.

The team also found that even though a large number of the schoolteachers had access to the guidelines of the PCNs for approaching environmental issues in a crossdisciplinary manner, only the science, biology, and geography teachers discussed environmental issues with their classes. A few projects with an emphasis on nature preservation had also been developed, but they had been characterized by the teachers as presenting a list of "environmentally correct" attitudes to be followed without detailing and exploring the different dimensions (ecological, economic, aesthetic, historical, social) of the problem discussed.

The lack of a specific formation course in environmental education aimed directly at teachers was one of the factors limiting the elaboration of an effective proposal in this area.

The initiatives of the Regional Education Nucleus were limited to presenting the PCNs and their principles and objectives without any further detailed work alongside schoolteachers that could lead them to learn new theoretical and methodological guidelines or develop a new approach to integrating the environment into education.

Another limiting factor to the development of environmental education was the lack of bibliographical and teaching materials on the subject. The majority of schoolteachers had access to the guidelines of environmental education only through the PCNs, and the schoolbooks used in class did not feature information on the realities of the region, which made it difficult to put the course content into the context of local problems during classes.

Also missing were the motivation and knowledge necessary to develop a program that would engage the school community as a whole, with the participation of teachers from several areas of knowledge, under the framework of an interdisciplinary activity.

Faced with this scenario, the discussion between the UEM professor and the schoolteachers led to a common objective: the development of a Continuing Education Program in Environmental Education.

Fifteen professors took part in the program, ages 24 to 56 , from various areas of knowledge: biology, sciences, geography, art education, physical education, history, informatics, English, mathematics, Portuguese and chemistry.

During planning for the Continuing Education Program in environmental education, it was emphasized that throughout the activities (workshops, study groups, lectures) the teachers should experience a continuous process of creation, reflection and action on the pedagogical and methodological issues entailed in their environmental education practices.

Table 1 presents the main topics developed during the program.

The workshop conducted during the first year of the program used questionnaires and group discussions to investigate opinions about "the environment". Authors such as Reigota (1998) and Sato (2003) have emphasized the importance of knowing more about teachers' representations of the environment - in other words, finding out how they see and perceive environmental problems in order to better understand their pedagogical practices.

We verified that the majority of teachers perceive the environment as a "means or place to live" or as "nature", as demonstrated by some of the following phrases:

"It's the collection of flora, fauna and physical environment that enable diverse life actions in the Planet".

"The space in which we live, the space we occupy and from which we extract the essentials of life".

"It's nature, it's ecology".

"It's the collective heritage of humanity, because it is the source of life, which is formed by the elements produced by nature itself'.

"It's all that surrounds us: soil, water, plants and animals",

In order to expand on the knowledge about the theme, a lecture titled "Capturing the notions of environment in the kaleidoscope of knowledge", given by a graduate student, helped teachers problematize and reflect upon the concept of "environment".

According to the teachers, many of the environmental education practices developed at the school were promoted basically by the sciences or biology teachers, with an emphasis on ecological aspects. However, as argued by Layrargues (1999), "The complexity of the environmental issue transcends ecological aspects, and orbits the political-ideological sphere". According to that author, "It is not nature that is in disharmony, but rather our society", and as such, during the practice of environmental education we must consider, in addition to ecological aspects, the contents of other areas of knowledge by making use of an interdisciplinary focus.

In this stage, many teachers made progress in perceiving that in order to understand and work with the complexities of environmental phenomena and problems, it is necessary to conceive the environment in its 
Table 1. Continuing Education Program in Environmental Education. Years: 2003 to 2007.

Continuing Education Program in Environmental Education

2003 Environment, Sustainable Development and Environmental Education

- Environmental representations by the teachers

- Definitions, history, objectives and methodologies

Interdisciplinary Projects at school

- Fundamentals and practices

2004 Reflecting on educational practice

- What is my current educational practice? Which theories form the basis of my practice? Why do I develop this practice? How can I change my educational practice?

Discussing theoretical approaches in education

- Traditional, Technical, Humanistic, Socio-cultural, Historical-Critical, Constructivist

2005 Building new knowledge to work with environmental education

- The contribution of the pedagogy of Paulo Freire to the praxis of environmental education

- What does it mean to 'evaluate'? How to evaluate changes in behaviors and attitudes? What are the evaluation techniques and instruments in Environmental Education?

2006/2007 School Agenda 21

Reflecting on diverse themes

- Education and Complexity, Critical Theory, Transdisciplinarity, Learning Communities,

Knowledge-Building, Educational Intervention, Collective Educators, Praxis Pedagogy,

Environmental Curriculum and Education, Democracy, Communication for Collective

Educators, Socio-biodiversity. (Source: Brasil, 2005)

totality, considering the ecological, cultural and socioeconomic dimensions.

Although the teachers already had experience in environmental education, many questions, obstacles and challenges still limited their pedagogical activities. The lack of fundamentals to develop the "environment" theme became evident when the teachers expressed difficulties in conveying the theoretical references adopted, delineating the objectives, selecting work methods and strategies, and evaluating the results obtained in the projects. The teachers felt insecure as to their theoretical and methodological options for developing an environmental education project.

Nevertheless, over the five years of the program, their work in collaboration with UEM researchers enabled schoolteachers to investigate and reflect on their own theoretical conceptions and pedagogical practices, build new sets of knowledge and create new teaching strategies with which to work on environmental issues (Obara, et al., 2003; Obara et al., 2006; Obara et al, 2007).

The development of interdisciplinary projects was one methodological strategy adopted by the group in an attempt to articulate the different areas of knowledge and integrate various didactic resources and activities while considering local socio-environmental problems.

\subsection{Development of interdisciplinary projects}

The activities and discussions conducted during the "Interdisciplinary Projects at School" course enabled schoolteachers to (re)evaluate previously developed projects of environmental education, identify limitations and revise concepts and strategies, with the objective of building a new project structured on more solid theoretical and methodological foundations.

In spite of the debate over the fact that interdisciplinarity has gained ground within education in Brazil by aiming to overcome specialized and fragmented education - which limits comprehension of the complex interrelations of the natural and cultural phenomena that permeate our lives - teachers still have much difficulty in incorporating this new form of organizing and presenting knowledge into their educational practices. According to Carvalho (1998):

[...] the adoption of an interdisciplinary proposal implies a profound change in the forms of teaching and learning, as well as in the formal structure of educational institutions. Thus, an interdisciplinary stance will require a remarkable openness to change - which can span, for instance, the construction of new methodologies, the restructuring of curricular themes and contents, the organization of teams of teachers that cover the different areas of knowledge, and by educational institutions to have the flexibility and willingness to try new forms of organizing professionals, curricula and contents, the formal grade level structure, etc. Precisely because it opposes the common conception of the nature of knowledge, the interdisciplinary proposal is not easily assimilated. What frequently occurs is an only partial comprehension of the concept of interdisciplinarity, its origins and consequences for educational practice. 
It must not be reduced into a collection of disciplines, but rather a collective school commitment to overcoming this manner of dealing with knowledge, based on modern rationality, of the fragmentation of the whole into several parts requiring specialized knowledge as a strategy to understand the world. The active engagement of schoolteachers is essential to a critical framework of transforming school reality.

To that end, every year the group (teachers, students and UEM researchers) collectively compiles an interdisciplinary project with the active involvement of teachers from several disciplines: sciences, Portuguese, literature, history, geography, mathematics, research, arts and physical education.

Starting with generating a theme, the classes and activities are organized by the group within the framework of structuring the problem of the environment in an interdisciplinary manner and a local context, based on the questioning educational concept proposed by Freire (1975).

The following generated themes were expanded: "Porto Rico: Natural Beauty and Environmental Problems", "Fauna and Flora in the region of Porto Rico - PR", "Environment: a Question of Citizenship", "Environmental perception and School Agenda 21: what is the school of our dreams?"

In addition to the activities planned by the faculty responsible for the various disciplines, workshops and lectures were also organized by UEM biologists, professors and graduate students. The workshops featured theoretical-practical classes in the field and in the lab, group discussions and games. The objective was to expand the ecological, economic and cultural knowledge of the school's students and teachers regarding Porto Rico and the Paraná River floodplain.

The themes of the workshops and lectures are presented in Table 2.

The value of the participation by UEM faculty and researchers in the development of the workshops was fundamentally in their sharing with school students and teachers their specific knowledge of the region's fauna and flora, which were obtained by the group during scientific stud- ies for PELD. The students had access to a vast range of biological material, developed activities and group discussions, performed research, and presented studies, among several other participatory activities, all of which contributed to a more intense learning of the relevant themes.

In 2006-2007, the proposal of inserting School Agenda 21 into the program was put forward with the expectation of facing, in a participative and cooperative manner, the main problems within the school environment. Vandalism of school property, violence, damaged gardens, trash, and poor discipline were some of the problems identified by the school community (Obara et al., 2007).

The project, undertaken with two classes - one of $5^{\text {th }}$ graders and another of 6th graders - was developed in five main stages. During the first stage, the aim was to give a lecture presenting the fundamentals and objectives of School Agenda 21. The second stage consisted of an investigation into the students' environmental perceptions regarding the school grounds. The students were asked to make a drawing based on the generating question, "What is the school of my dreams?" In the third stage, the students were instructed to photograph the areas of the school where they identified a problem and which they would be willing to help preserve or improve. In the fourth stage, the teachers developed knowledge related to the problems identified by making use of various pedagogical strategies: research, group work, workshops, field/lab classes, and group discussions, among others. It was observed that the great majority of students did not know of the existence of Agenda 21. The activities showed that the students presented various wishes, criticisms and expectations regarding the quality of the school space. Starting from the identification of the students' perceptions, attitudes and values relative to the school's feature elements and reflection on the problems raised by the students, a gradual process of valuation of the school space was observed (Roth et al., 2007).

\subsection{Inserting information and communication technologies}

Information and Communication Technologies (ICTs) have promoted greater interaction within the

Table 2. Main themes developed at the workshops and lectures - Years: 2003 to 2007.

\begin{tabular}{|c|c|}
\hline & Themes \\
\hline 2003 & $\begin{array}{l}\text { - The Paraná River floodplain: physical and biological aspects } \\
\text { - Fish of the Paraná River } \\
\text { - Porto Rico, Porto Pobre ("Rich Port, Poor Port”): historical, social and economic aspects } \\
\text { - Environmental education and natural areas } \\
\text { - Environmental sanitation in Porto Rico }\end{array}$ \\
\hline 2004 & $\begin{array}{l}\text { - Fish diseases: definition, biology and morphology } \\
\text { - Flora in the region of Porto Rico: definition, characteristics, importance and conservation }\end{array}$ \\
\hline 2005 & $\begin{array}{l}\text { - Upper Paraná River floodplain: ecological, cultural and historical aspects } \\
\text { - Planktonic communities and their importance in the food chains }\end{array}$ \\
\hline $2006 / 2007$ & $\begin{array}{l}\text { - Fundamentals and objectives of School Agenda } 21 \\
\text { - Climate changes: Myth or Reality }\end{array}$ \\
\hline
\end{tabular}


school through the internal network, as well as participation in cyber-culture by using the internet (Lévy, 1999).

The use of ICTs has made possible new forms of construction, cooperation and circulation of knowledge and information in various areas, thereby aiding in the formation of teachers and students and overcoming the limits of physical distance (Moran, 2006).

The impact of ICTs on society and education has sparked a true revolution that affects work as well as education and continuing studies, transforming our conceptions of the processes of teaching and learning how to learn (Guerra, 2001).

With the objective of introducing new forms of working and disseminating knowledge and scientific information within and between UEM, the schools and other institutions of education and research, two ICT insertion projects are being developed in the public schools of Porto Rico. As previously mentioned, a collaborative project has been developed between students and educators at state and municipal schools alongside UEM faculty and researchers, based on the action-research methodology (Thiollent, 2000). Since 2004, the Technologies in Environmental Education (TEdAm) project has been developed at the city's state school. The meetings, workshops and technical visits have enabled teachers and middle and high school students to hypertext create and maintain of website about environmental education, which serves as pedagogical support for the development of the environmental education projects implemented at the school.

Similarly to the municipal school, the Continuing Education Program in Environmental Education (PECEA) has worked to promote digital inclusion and continuing online environmental education for first to fourth-grade teachers. The teachers took part in pedagogical workshops on environmental education and became competent in the use of computer resources, especially those based on Internet environments, and the generation of cooperative projects. The researchers developed a website, called Gu@pi (http://www.wlab.info/guapi/pt/), which makes available information related to the environment in the region of the Upper Paraná River floodplain.

The periodical evaluations conducted in both projects reveal that the ICTs have altered the cultural habits of the schools by offering new forms of researching, learning and communicating. It was further possible to identify that the ICTs expanded the discussions between the acquired forms of knowledge constructed by the university and the Porto Rico school community regarding ecological, economic and cultural aspects of the floodplain, thus allowing a greater exchange of experiences in the hopes of effectively consolidating environmental education on the banks of the Paraná River (Silva-Dias et al., 2007; Corredato-Periotto and Tomanik, 2006).

\subsection{Production of teaching materials}

In 2006, the workgroup prioritized the elaboration of teaching support materials to promote pedagogical practice among schoolteachers.
In spite of the vast scientific literature (books, scientific reports, theses, dissertations and articles) already available on the Paraná River floodplain produced by Nupélia and by the Graduate Program in Ecology of Continental Aquatic Environments - UEM, the schoolteachers emphasized that the type of language used and the level of specialization of the topics being investigated represented obstacles in consolidating the process of environmental education in the local context.

The planning process for elaborating the teachinglearning material was conducted through a collaboration of teachers from the state school, UEM faculty and Nupélia researchers. The participation of the schoolteachers in the planning and development of the teaching support materials is essential as it is expected that the final product can better match the local reality based on their suggestions and experiences.

During the first stage in 2006, meetings were held with schoolteachers to assess their wants and needs in terms of teaching materials for use in discussing local environmental issues and also to evaluate the information and knowledge on the Paraná River floodplain contained in available school books, complementary works, and scientific publications. Some basic criteria were defined for the elaboration of textbooks, along with the necessary resources to compose a "field kit".

After the discussions, it was decided that the teaching support material must feature:

a) A series of textbooks containing information and data relative to the Paraná River floodplain ecosystem;

b) A CD with images (biological material, graphics, maps, etc.), exercises and suggestions of activities (field and lab) for use by teachers; and

c) A "Field kit" with a teaching manual and the main instruments and devices required for collections and analyses of environmental data in the field and in the lab (water quality, vegetation, ichthyology, and others).

During the second stage, still in 2006, the proposal was presented to the group of Nupélia researchers with the aim of expanding the discussion regarding the development of the textbooks, collectively constructing criteria for legibility and the selection of appropriate content, field practices and lab experiments. The materials to compose the "field kit" were suggested by the researchers, who have extensive experience in experimental and field work.

The last stage, which began in 2007, had the objective of the actual creation of the pedagogical materials. Each stage of textbook construction has been reviewed by the project coordinator and by middle and high school teachers for discussion and evaluation.

\section{Conclusion}

The collaborative work between faculty, researchers, graduate and undergraduate students at UEM and teach- 
ers and students from the public schools is an experience that has contributed significantly to the education of both groups. The action-research methodology makes it possible to make the practice of teaching an object of research so that the main problems and difficulties of inserting the environmental dimension into the school curriculum could be identified, problematized and evaluated.

In the case of university professors and researchers, the project provided situations in which it was possible to evaluate and reconsider the purpose of the teaching disciplines, as well as disciplines of specific areas (zoology, botany, ecology, etc.), in the formation of future faculty, who must be prepared to work in the various dimensions of the environmental thematic.

Graduate and undergraduate students, who are future faculty, also had the opportunity to participate in the activities and discussions conducted in the program and in the projects and to experience the limits and challenges of pedagogical practice in environmental education.

As for the schoolteachers, they have gradually assumed the profile of teacher/researchers who investigate and analyze each teaching and learning situation, reflect on the main problems of the teaching practice, and create new possibilities for intervention, enacting their action-reflections.

The collaborative work between faculty and researchers at UEM and teachers from the public schools reduced the distance between these learning institutions, enabling the exchange of experience and knowledge, as well as advancements in pedagogical practice, by all involved.

The evaluations of the most recent five years of the project allow for a few considerations:

- Schools must constitute a space for continuous and permanent formation of teachers/researchers, both for initial and continuing education;

- The studies conducted by Nupélia and by the Graduate Program in Ecology of Continental Aquatic Environments must be integrated with the Continuing Education Program in Environmental Education in order to promote the pedagogical practice of faculty;

- Participation by a greater number of university professors and researchers from various areas of expertise (agronomy, biology, social sciences, law, economics, education, nursing, civil engineering, chemical engineering, philosophy, physics, geography, history, mathematics, psychology, and chemistry, among others) in environmental education projects must be encouraged in the hopes of expanding the vision of the natural and cultural reality of the Paraná River floodplain; and

- The Continuing Education Program in Environmental Education must be expanded to the other learning institutions and segments of society (fishermen, farmers, river-dwellers and the community in general) that are part of the Upper Paraná River floodplain, and thus contributing to the strengthening of the principles of environmental education in the floodplain as a whole.
Acknowledgements - We wish to thank the faculty and students from both schools in Porto Rico - PR, as well as the professors, researchers, and graduate and undergraduate students from UEM, for sharing their dreams and knowledge with the authors. Special thanks to those who administered the courses, lectures and workshops: Prof. Edson Ikeda, MS; Prof. Fúlvia Eloá Maricato, MS; Prof. Paulo Inada, MS; Dr. Janet Higuti, Graduate Luiz Tavares de Sá, Graduate Eliza Akane Murakami, Graduate Sirlene Aparecida Felisberto, Graduate Mara Glacenir Lemes de Medeiros, Graduate Irausa Arroteia Fonseca, Graduate Carina Moresco, Graduate Ana Cristina Libanore, Graduate Yara Moretto Bagatini, Graduate Anelize Queiroz Amaral, Undergraduate Thaise Roth, Undergraduate Fábio Alves Correa, Undergraduate Bruno Rogério Ártico, Msc Eliana Campagnolo (Biology).

\section{References}

BRASIL. Ministério do Meio Ambiente, 2005. Encontros $e$ caminhos: formação de educadoras (es) ambientais e coletivos educadores. Brasília: Coordenação Ferraro Júnior, LA. 358p.

CARVALHO, ICM., 1998. Em direção ao mundo da vida: interdisciplinaridade e educação ambiental. Brasília: IPÊ. 102 p.CORREDATO-PERIOTTO, TR. and TOMANIK, EA., 2006. Environmental education at distance: implementation and evaluation of a project to teach about flood plain of the Upper Raraná river. In Proceedings of the 22nd ICDE World Conference on Distance Education, September 3-6. Rio de Janeiro: ABED. p. 1-7.

DIAS, GF., 1992. Educação ambiental: princípios e práticas. São Paulo: Gaia. 399p.

FREIRE, P., 1975. Pedagogia do oprimido. 3 ed. Rio de Janeiro: Paz e Terra. 218p.

GUERRA, AFS., 2001. Navegando na Web em busca de intervenções em educação ambiental: a interdisciplinaridade e a transversalidade em ação. In SANTOS, JE. and SATO, M. (Orgs.). A contribuição da educação ambiental à esperança de Pandora. São Carlos: RiMa. 604p.

GUERRA, AFS. and TAGLIEBER, JE., 2007. Desafios e reflexões na busca da inserção da dimensão ambiental na formação docente no sul do Brasil. In Anais do I Congreso Internacional de Educación Ambiental dos países lusófonos e Galícia, September 24-27. Santiago de Compostela: Espan. p. 1-18. 1 CD-ROM.

GUIMARÃES, M., 2004. A Formação de Educadores Ambientais. São Paulo: Papirus. 174p.

LAYRARGUES, PP., 1999. A resolução de problemas ambientais locais deve ser um tema gerador ou atividade-fim da Educação Ambiental? In REIGOTA, M. (Org.). Verde Cotidiano: o meio ambiente em discussão. Rio de Janeiro: DP\&A. p. 131-148.

LÉVY, P., 1999. Cibercultura. São Paulo: Editora 34. 260p.

LUCATTO, LG. and TALAMONI, JLB., 2007. A construção coletiva interdisciplinar em educação ambiental no ensino médio: a microbacia hidrográfica do ribeirão dos Peixes como tema gerador. Ciência \& Educação, vol. 13, no. 3, p. 389-398.

MATEUS, CE. and SÉ, JAS., 2003. Educação ambiental e recursos hídricos: uma abordagem holística e sistêmica de bacia hidrográfica. In NOAL, FO. and BARCELOS, VHL. (Orgs.). Educação ambiental e cidadania: cenários brasileiros. Santa Cruz do Sul: EDUNISC. p. 137-167. 
MEDEIROS, MGL., 2000. Educação Ambiental como educação científica: desafios para se compreender ambientes sob impactos. Maringá: Universidade Estadual de Maringá UEM. 175p. Dissertação de Mestrado.

2003. Signos Naturais e culturais em Porto Rico: educação ambiental e semiótica em uma microregião da planície de inundação do alto do rio Paraná, PR, Brasil. Maringá: Universidade Estadual de Maringá - UEM. 191p. Tese de Doutorado.

MEDINA, NM., 2002. Formação de multiplicadores para Educação ambiental. In PEDRINI, AG. (Org.). O Contrato Social da Ciência, unindo saberes na Educação Ambiental. Petrópolis: Vozes. p. 69-90.

MORAN, JM., 2006. Desafios da Internet para o professor. Available from: <http://www.eca.usp.br/prof/moran/desaf_inf. htm>. Access in: 24 de Fevereiro de 2006.

OBARA, AT., PEREIRA, S. and NAVASCONI, CLRD., 2003. Educação Ambiental no ensino formal: a experiência do colégio Manoel Romão Netto (Porto Rico - PR). In Anais do II Simpósio Sul Brasileiro de Educação Ambiental - I Encontro da Rede Sul Brasileira de Educação Ambiental - I Colóquio de Pesquisadores em Educação Ambiental da Região Sul. December 7-10. Itajaí: UNIVALI; FNMA; REASul; Mater Natura; CEPSUL; IBAMA. 1 CD-ROM.

OBARA, AT., DIAS-SILVA, MAG., SUZUKI, HI. and TAKEMOTO, R., 2006. Educação continuada em educação ambiental. In. UNIVERSIDADE ESTADUAL DE MARINGÁ. Nupélia/PELD. (Orgs.). A planície de inundação do alto rio Paraná: Site 6 PELD/CNPq. Maringá, 2006. Relatório anual 2006. Available from: <http://www.peld.uem.br/Relat2006/ pdf/18_Educacao_Ambiental.pdf $>$. Access in: 20 de Agosto de 2008.

OBARA, AT., OBARA, AT., DIAS-SILVA, MAG., SUZUKI, HI. and TAKEMOTO, R., 2007. Educação continuada em educação ambiental. In. UNIVERSIDADE ESTADUAL DE MARINGÁ. Nupélia/PELD. (Orgs.). A planície de inundação do alto rio Paraná: Site 6 PELD/CNPq. Maringá, 2007. Relatório anual 2007. Available from: <http://www.peld.uem.br/Relat2007/pdf/ capitulo_20.pdf>. Access in: 20 de Agosto de 2008.

REIGOTA, M., 1998. Meio ambiente e representação social. São Paulo: Cortez. 87p.

ROTH, T., AMARAL, AQ. and OBARA, AT., 2007. Percepção ambiental e agenda 21 escolar: qual a escola de nossos sonhos.
In Anais do X Encontro Paranaense de Educação Ambiental, October 26-28. Maringá: Universidade Estadual de Maringá UEM. 1 CD-ROM.

SATO, M., 2003. Educação Ambiental. São Carlos: RiMA. $65 \mathrm{p}$.

SCOULLOS, M. and MALOTIDI, V., 2005. Manuel sur les méthodes utilisées pour l'Education à l'Environnement et l'Education pour le Développement Durable. Athènes: MIOECSDE. 111p.

SILVA-DIAS, MAG., OBARA, AT., ARTICO, BR. and MARCOLLI, AGM., 2007. Tecnologias de informação e comunicação à educação ambiental continuada no ensino médio e fundamental às margens do rio Paraná, Porto Rico-PR, Brasil - TEdAm. In Resumos do X Encontro Paranaense de Educação Ambiental, October 26-28. Maringá: Universidade Estadual de Maringá - UEM. 1 CD- ROM.

TAGLIEBER, JE., 2004. Reflexões sobre a formação docente e a Educação Ambiental. In ZAKRZEVSKI, SB. and BARCELOS, V. (Org.). Educação ambiental e compromisso social: pensamentos e ações. Erechim: EdiFAPES. p. 13-23.

THIOLLENT, M., 2000. Metodologia da pesquisa-ação. 8 ed. São Paulo: Cortez. 108p.

TOMANIK, EA. and TOMANIK, MC. 2002. O ambiente conhecido: estudo das representações sociais sobre natureza, compartilhadas pelos adolescentes de Porto Rico, Paraná. In UNIVERSIDADE ESTADUAL DE MARINGÁ. Nupélia/ PELD. (Orgs.). A planície de inundação do alto rio Paraná: Site 6 PELD/CNPq. Maringá, 2002. Relatório anual 2002. Relatório PELD. Available from: <http://www.peld.uem.br/Relat2002/ peld-reltec02-Comp_Soc_Econ.htm\#Ambiente>. Access in: 13 de Janeiro de 2004.

TOZONI-REIS, MFC., 2007. Formação de educadores ambientais pela pesquisa-ação-participativa. In Anais do IV Encontro de Pesquisa em Educação Ambiental, July 15-18. Rio Claro: UNESP. 1 CD-ROM.

TRISTÃO, M., 2004. Educação Ambiental na formação de professores: redes de saberes. São Paulo; Vitória: Annablume; FACITEC. $225 \mathrm{p}$

ZAKRZEVSKI, SBB. and SATO, M., 2001. Refletindo sobre a formação de professoras em Educação Ambiental. In SANTOS, JE. and SATO, M. (Org.). A contribuição da Educação Ambiental à esperança de Pandora. São Carlos: RiMA. p. 63-84. 